\title{
Significance of transition between Talchir Formation and Karharbari Formation in Lower Gondwana basin evolution - A study in West Bokaro Coal basin, Jharkhand, India
}

\author{
H N Bhattacharya ${ }^{1}$, Abhijit Chakraborty ${ }^{2}$ and Biplab Bhattacharya ${ }^{1}$ \\ ${ }^{1}$ Department of Geology, Presidency College, Calcutta 700 073, India. \\ ${ }^{2}$ Department of Geology, Jogamaya Devi College, 92 S.P. Mukherjee Road, Calcutta 700 026, India.
}

\begin{abstract}
Basal part of the Gondwana Supergroup represented by Talchir and Karharbari Formations (Permo-Carboniferous) records an abrupt change-over from glacio-marine to terrestrial fluviolacustrine depositional environment. The contact between the two is an unconformity. Facies analysis of the glacio-marine Talchir Formation reveals that basal glaciogenic and reworked glaciogenic sediments are buried under storm influenced inner and outer shelf sediments. Facies associations of the Karharbari Formation suggest deposition as fluvio-lacustrine deposits in fault-controlled troughs. An attempt has been made in this paper to explain the sedimentation pattern in Talchir and Karharbari basins, and the abrupt change-over from glacio-marine to terrestrial fluviolacustrine depositional environment in terms of glacio-isostacy.
\end{abstract}

\section{Introduction}

Predominantly continental freshwater sediments belonging to the Gondwana Supergroup accumulated during late Carboniferous to early Cretaceous period, are found to occur in a number of isolated basins along several paleo-rift valleys in peninsular India (Chatterjee and Ghosh 1970). The basal unit of the Gondwana Supergroup, the PermoCarboniferous Talchir Formation, is dominantly glaciogenic, with associated fluvial and lacustrine or marine facies (Ghosh and Mitra 1967, 1975; Casshyap and Qidwai 1971, 1974; Casshyap and Tewari 1982, 1988; Bose et al 1992; Bhattacharya et al 2002). Sedimentological and paleontological attributes of the Talchir Formation are distinctly different from the younger fluviatile coal-bearing Gondwana succession (Reed 1928; Ghosh 1954; Dutta 1965; Bhattacharya et al 1989; Mukhopadhyay and Bhattacharya 1994; Sengupta et al 1999).

The Permo-Carboniferous sedimentary succession, the lower most part of the Gondwana Supergroup, exposed along Dudhi nala (streamlet) in
West Bokaro Coal basin, Hazaribagh, Jharkhand records an abrupt change from glacio-marine Talchir Formation to fluviatile coal-bearing Karharbari Formation (Ghosh and Mitra 1967; Bhattacharya et al 1989; Bose et al 1992; Mukhopadhyay and Bhattacharya 1994). Climatic shift is considered to be responsible for such a change (Veevers and Tewari 1995 and references therein). However, in rift-settings, tectonic causes may usher in such abrupt changes in basin morphology and depositional system. In this paper, a re-examination of these two formations and their relationship is carried out in the West Bokaro basin with the aim of constraining the controlling factors that were responsible for such an abrupt change-over.

\section{Geological setting}

The Talchir Formation in the Dudhi nala section, West Bokaro basin, unconformably overlies the Precambrian basement represented by granitoids and amphibolites (figure 1). The basal part

Keywords. Talchir Formation; Gondwana Supergroup; Glacio-marine sediments; fluvio-lacustrine; glacio-isostacy. 


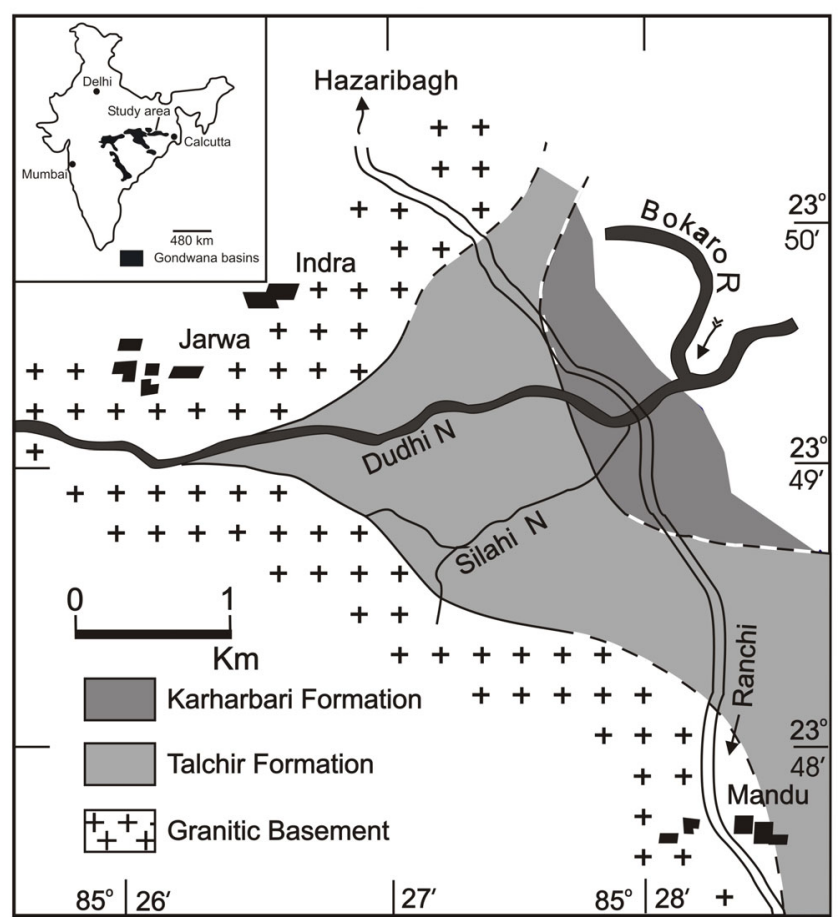

Figure 1. Geological map showing Talchir Formation and Karharbari Formation in the western part of West Bokaro Coal basin.

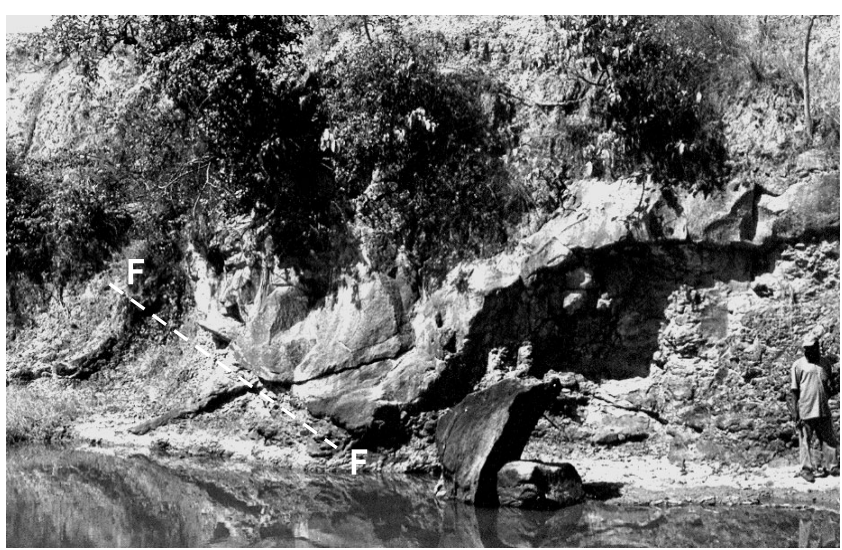

Figure 2. Normal fault developed in Talchir sediments close to the contact with Karharbari sediments.

of the Talchir Formation comprises conglomerates commonly referred to as 'Talchir Boulder Bed', and is overlain by a thick succession of greenish sandstone and shale deposited in open shelf environments (Bhattacharya et al 1989; Bose et al 1992; Mukhopadhyay and Bhattacharya 1994). Sengupta et al (1999) reported marine fossil Polyplacophora from this succession. The glacio-marine Talchir succession is overlain by the coal bearing fluviatile succession of the Karharbari Formation. The contact relationship between the Talchir Formation and the Karharbari Formation has not yet been properly established. The basal part of the Karharbari Formation is dominated by conglomerates and

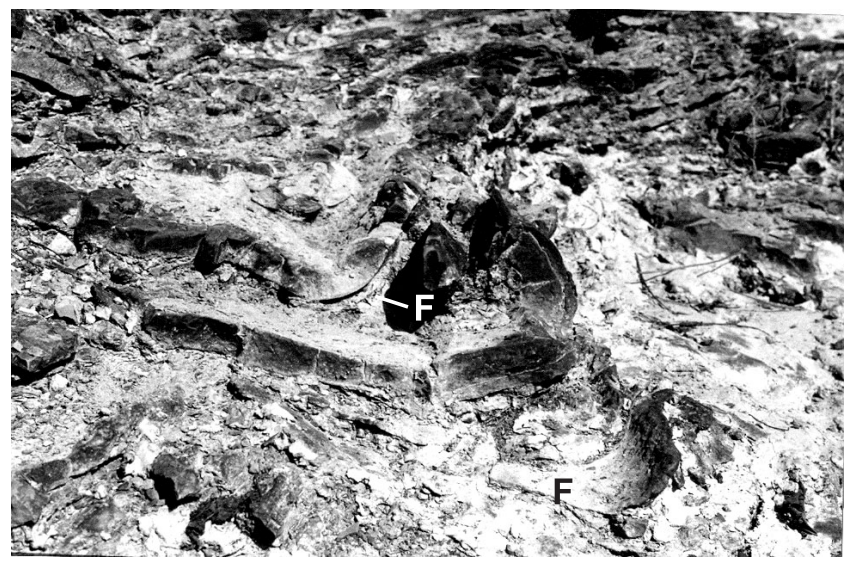

Figure 3. Drag folds developed in Talchir sediments.

pebbly-sandstone, whereas the upper part is represented by coarse-grained sandstone with carbonaceous shale and coal partings.

A series of close spaced faults, both normal and reverse, are developed within Talchir sediments close to the contact with Karharbari rocks (figure 2). The attitude of the faults is more or less similar with the attitude of the contact between the Talchir and Karharbari successions. Drag folds are developed in centimetre to metre scale in the vicinity of the faults (figure 3 ). The bedding dip of basal Karharbari rocks is steeper $\left(20^{\circ}\right.$ to $25^{\circ}$, northerly), but becomes horizontal towards the top.

\section{Talchir Formation}

Three major facies associations may be identified in the sedimentary succession of the Talchir Formation exposed in the Dudhi nala section. These are conglomerate-sandstone facies association (TCS), sandstone-siltstone facies association (TSS) and fine sandstone-mudstone facies association (TSM). Conglomerate-sandstone-silty mudstone association developed as a cover succession over the conglomerate-sandstone association and basement granitoids as well. Fine sandstone-mudstone association occupies the eastern part of the nala section and the upper half of the stratigraphic column of the Talchir Formation.

\subsection{Facies analysis}

\section{1a Conglomerate-sandstone facies association (TCS)}

This facies association is represented by jagged breccia (TCS-1), stacked tabular clast conglomerate (TCS-2), massive sandstone (TCS-3), reverse graded conglomerate-sandstone alternations (TCS-4), matrix- and clast-supported conglomerates with angular and rounded clasts (TCS-5 


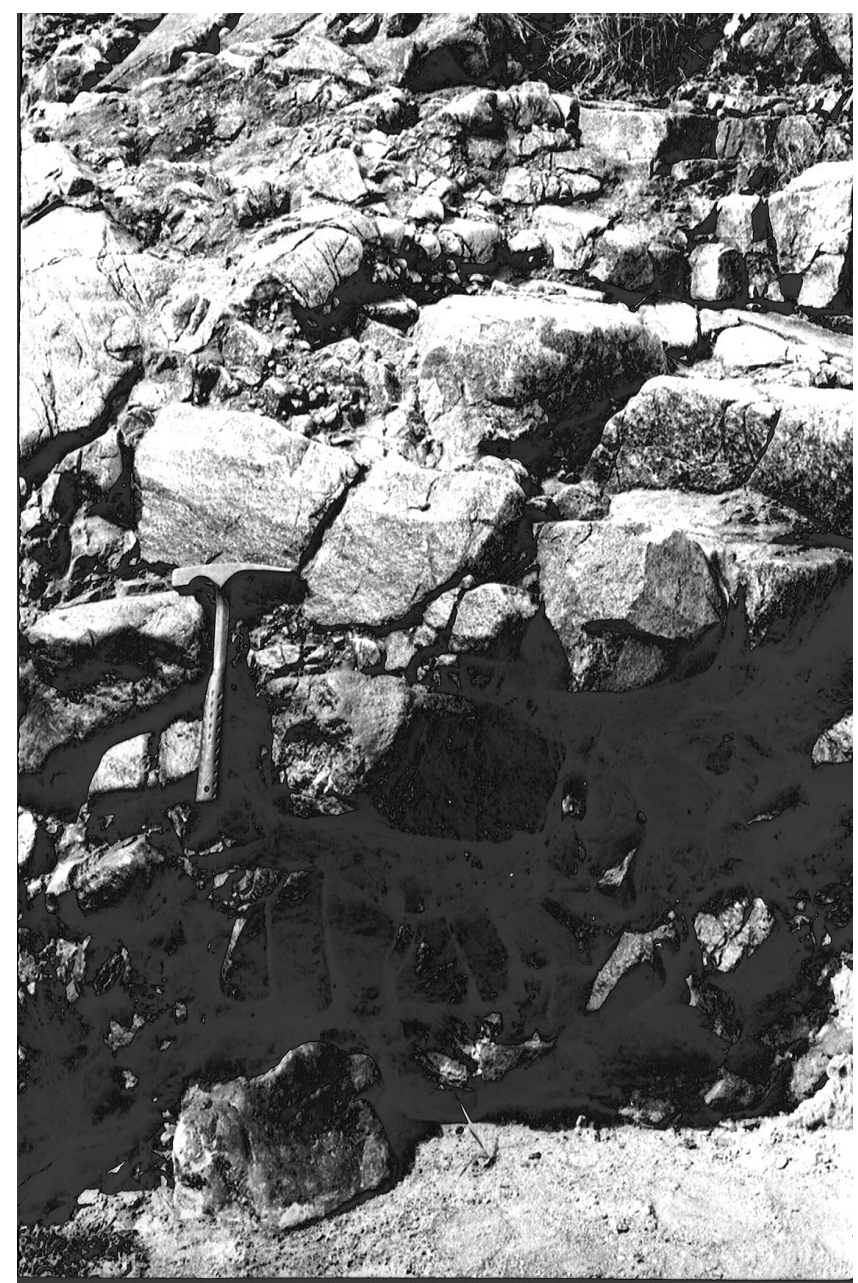

Figure 4. Stacked tabular boulder conglomerate, lodgement tillite in conglomerate-sandstone facies association, Talchir Formation.

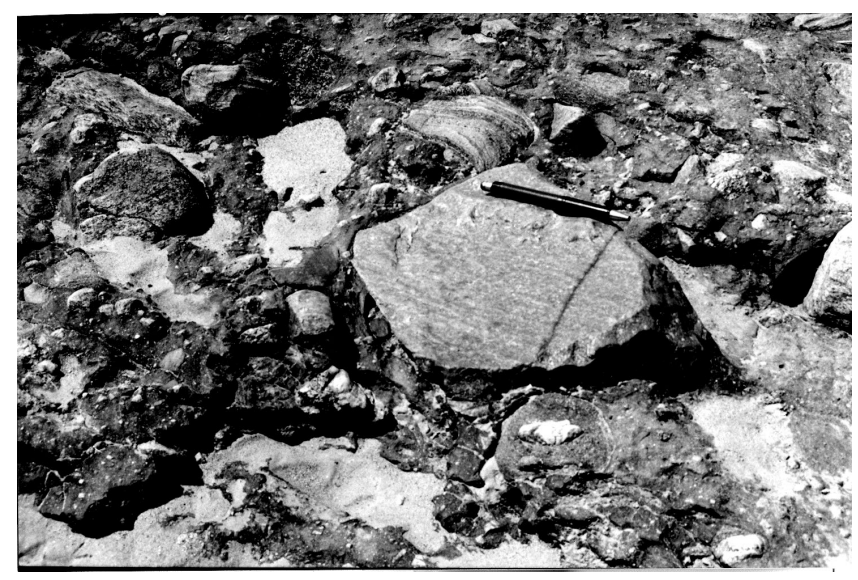

Figure 5. Field photograph of faceted and striated clast in tabular clast-supported conglomerate (TCS-2) of conglomerate-sandstone facies association, Talchir Formation.

and TCS-6), gravelly sandstone (TCS-7) and normally graded sandstone (TCS-8). Random variability in bed thickness, rapid transition among

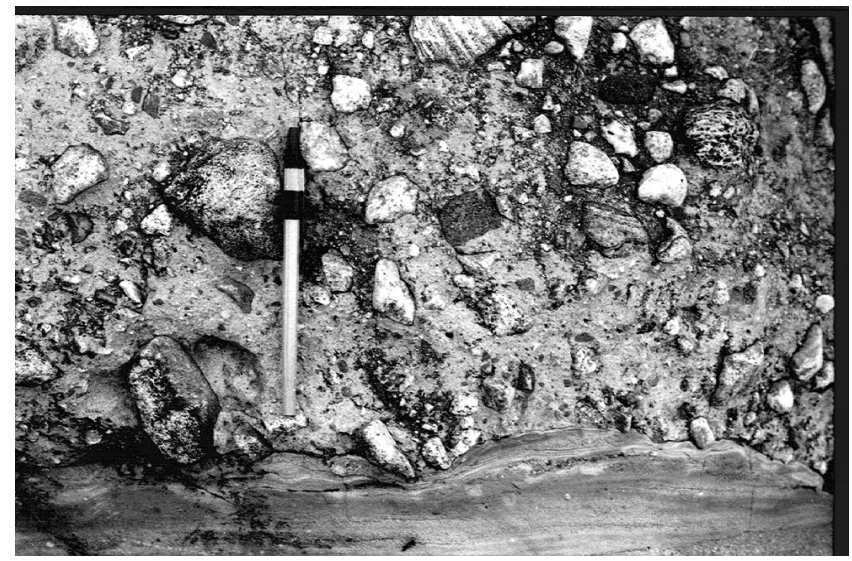

Figure 6. Matrix-supported conglomerate with angular clasts. Note deformation of laminations in the underlying sandstone, conglomerate-sandstone facies association, Talchir Formation.

the facies types and difference in clast shape, size and composition in different conglomeratic facies are the marked characteristics of this facies association.

The jagged breccias (TCS-1) occur as a thin (40 to $75 \mathrm{~cm}$ ) skin over bedrock, and give way downslope to stacked tabular boulder conglomerates (TCS-2) (figure 4). Surfaces of the granitoid boulders are in general, faceted and striated (figure 5). The matrix between the boulders is sheared silty sandstone. Massive sandstone (TCS3 ), filling irregular fractures (in metre scale) in granitic basement, is exposed near the contact with Talchir rocks. Facies types such as reverse graded conglomerate-sandstone alternations (TCS-4), matrix- to clast-supported conglomerates with rounded or angular clasts (TCS-5 and 6) (figure 6), gravelly sandstone (TCS-7) and graded sandstone (TCS-8) are well preserved in a westerly closing trough like depression. Dropstones are common in these facies (TCS 4-8). Stratigraphic architecture of facies types in this facies association is shown in figure 7 .

The jagged breccias are the product of intense fracturing of bedrock under the glacier (cf. Boulton 1978). Massive sandstone, filling fractures in the basement rocks, is the product of emplacement of fluidized sand along fractures in the basement rocks under the glacier. Stacked tabular boulder conglomerates with sheared matrix are interpreted as lodgement tillite (Bose et al 1992; also see Visser and Hall 1985). Conglomerates (TCS-5 and TCS6 ), conglomerate-sandstone alternations (TCS-4), gravelly sandstone and normally graded sandstone (TCS-7 and TCS-8) represent resedimented deposits emplaced by various types of sediment gravity flows such as debris flow, modified grain flow and turbidity current (Bose et al 1992; also 

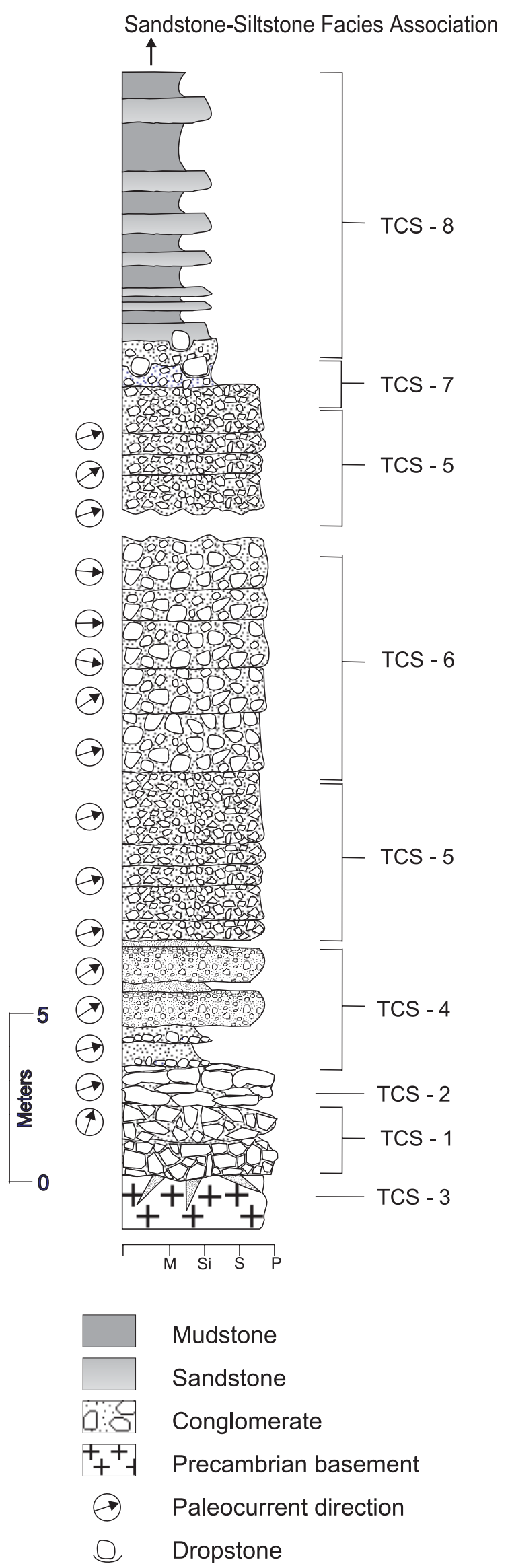

Figure 7. Measured litholog of the conglomerate-sandstone facies association of Talchir Formation, Dudhi nala. see Bhattacharya et al 2002). The presence of dropstones in different facies (TCS-4 to 8) indicates that the facies association developed as reworked glaciogenic deposits in front of the grounding line of the glacier under the sea.

\section{1b Sandstone-siltstone facies association (TSS)}

This facies association overlies the TCS association. It is represented by plane laminated mature sandstone with parting lineation (TSS-1), channel-fill fine sandstone (TSS-2), hummocky cross-stratified fine sandstone (TSS-3), normally graded sandy siltstone (TSS-4) and clastsupported conglomerate (TSS-5). The stratigraphic architecture (figure 8) of the facies units of this facies association reveals development of six fining upward sequences, with clast-supported conglomerate (TSS-5) at the base.

The plane laminated sandstone facies (TSS-1) shows a high degree of textural maturity. The bedding plane surfaces are parting lineated and locally contain adhesion ripples (cf. Mukhopadhyay and Bhattacharya 1994). The channels are flat and have very high channel width:height ratio (figure 9). The channel-fill fine sandstone (TSS2 ) is plane laminated near the base and is followed upward by ripple drift cross-lamination and combined flow ripple lamination. Ice-rafted debris is rare in this facies. Hummocky crossstratified fine sandstone (TSS-3) (figure 10) occurs as blanket sediments covering the conglomeratesandstone facies association. The hummocky crossstratified fine sandstone grades upward to normally graded and plane laminated sandy siltstone, combined flow ripple cross-laminated siltstone, and then to silt streaked mudstone. Normally graded sandy siltstone (TSS-4) in this facies association is sharp based and shows normal grading of grain size from coarse pink sand to green silt. Thickness of such graded beds varies from less than a centimetre to $5 \mathrm{~cm}$. Ice-rafted pebbles (1 to $12 \mathrm{~cm}$ ) are common in this facies. This facies is also characterized by common occurrence of softsediment deformation structures like convolutes (figure 11), flames, graben-like downsagging structures and synsedimentary faults. Clast-supported conglomerate lenses (TSS-5) occur at different stratigraphic levels. The conglomerates are less than $1 \mathrm{~m}$ thick and commonly show reverse grading near the base and chaotic fabric near the top. Clasts are very often faceted, vary from 3 to $40 \mathrm{~cm}$ in size, and are rounded. Clast composition is dominated by quartzite; granite and amphibolite clasts occur in subordinate proportion. A few big boulders (average diametre $35 \mathrm{~cm}$ ) of cross-stratified 


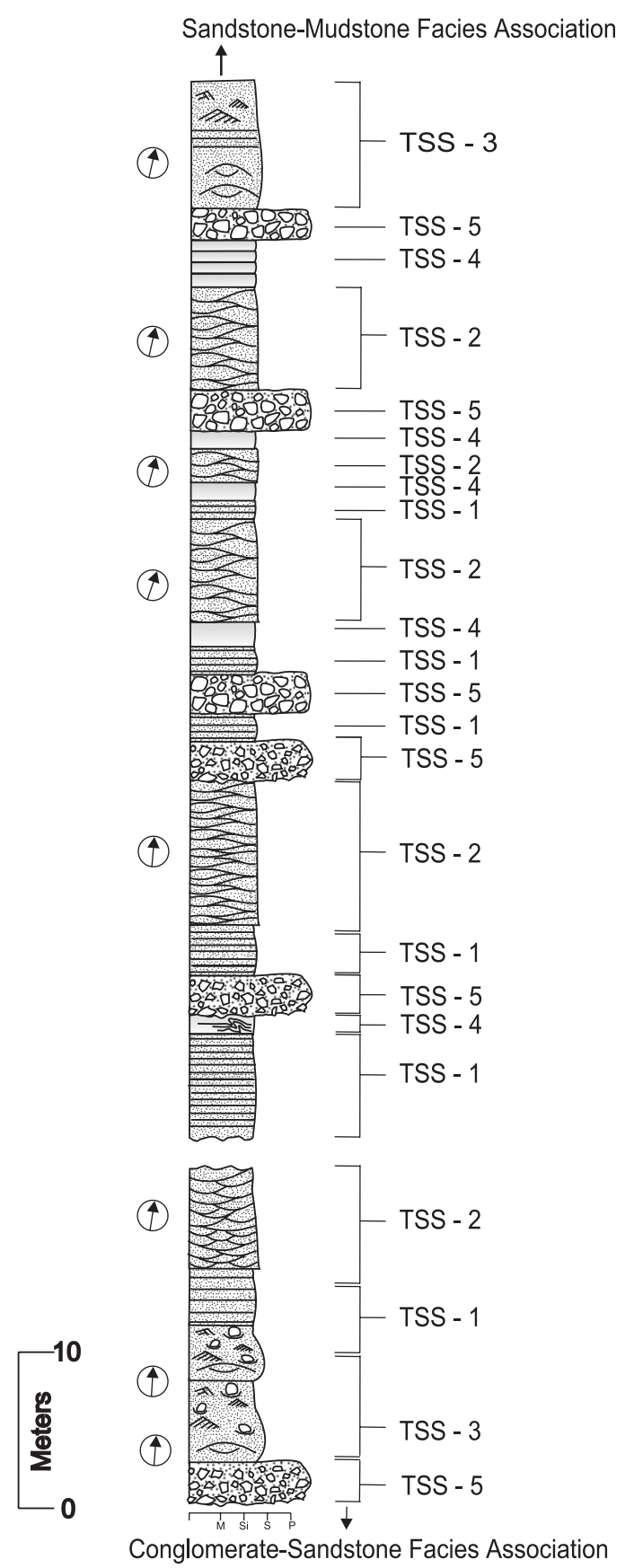

\begin{tabular}{|c|c|}
\hline & Graded silty-sandstor \\
\hline & Sandstone \\
\hline 68 & Conglomerate \\
\hline & Channels \\
\hline & $\begin{array}{l}\text { Hummocky cross } \\
\text { stratification }\end{array}$ \\
\hline & $\begin{array}{l}\text { Ripple cross } \\
\text { laminations }\end{array}$ \\
\hline & Slump folds \\
\hline & Paleocurrent direction \\
\hline & Dropstone \\
\hline
\end{tabular}

Figure 8. Measured litholog of the sandstone-siltstone facies association of Talchir Formation, Dudhi nala.

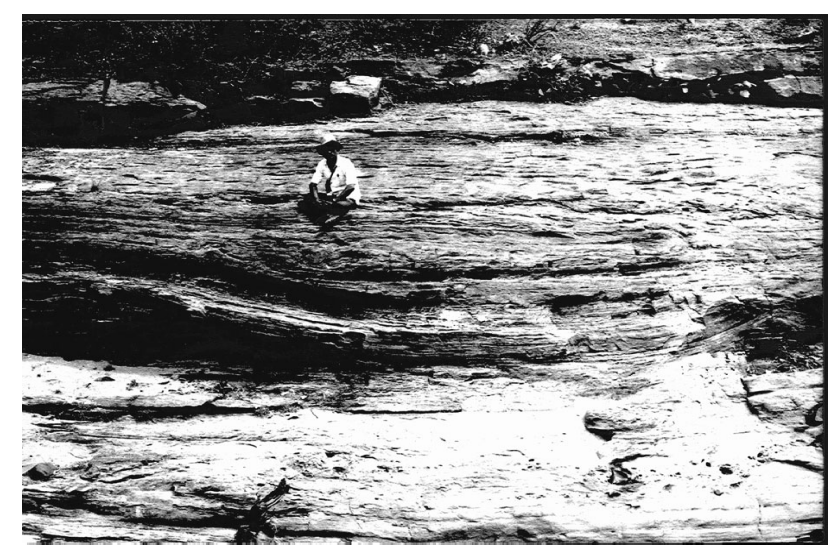

Figure 9. Channel fill sediments in sandstone-siltstone facies association, Talchir Formation.

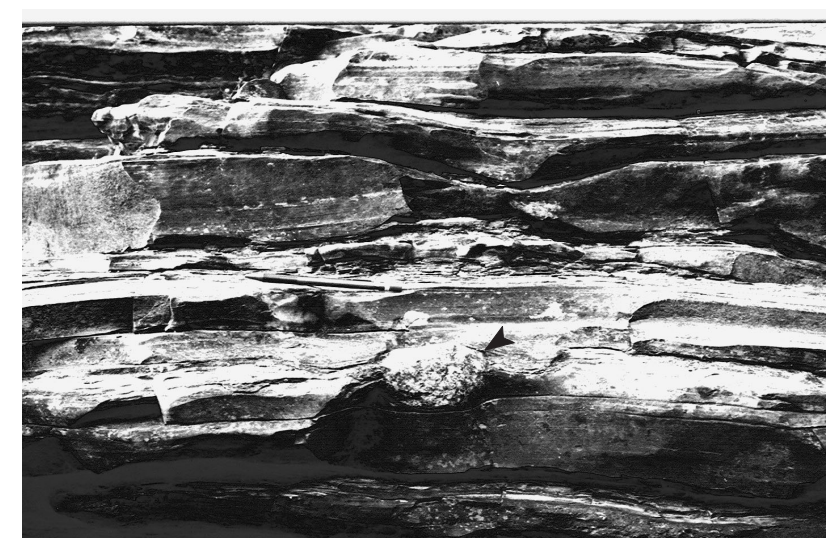

Figure 10. Hummocky cross-stratified fine sandstone in sandstone-siltstone facies association, Talchir Formation. Note the presence of a dropstone (arrow marked).

red sandstone are present in this conglomerate. The basal contacts of the conglomerate beds are scoured with the development of shear planes immediately below or above the contact.

The plane-laminated sandstone with parting lineation and adhesion ripples is interpreted as shoreface beach deposit. The channel-fill fine sandstone, hummocky cross-stratified fine sandstone and normal-graded sandy siltstone are different manifestations of storm deposition in shelf setting. The channels are attributed to storm-generated rip current and the channel-filling pattern suggests deposition from waning storm surges above storm wave base (cf. De Raaf et al 1977). The bedform asymmetry and internal organization of hummocky cross-stratified beds also attest to their origin from storm-generated combined-flows (Myrow and Southard 1991). The normal-graded sandy siltstones are probably storm-laid sublittoral sand sheets (Goldring and Bridges 1973; Nelson 1982). The soft-sediment deformation structures point to synsedimentary seismic activity (cf. Bhattacharya and Bandyopadhyay 1998). 


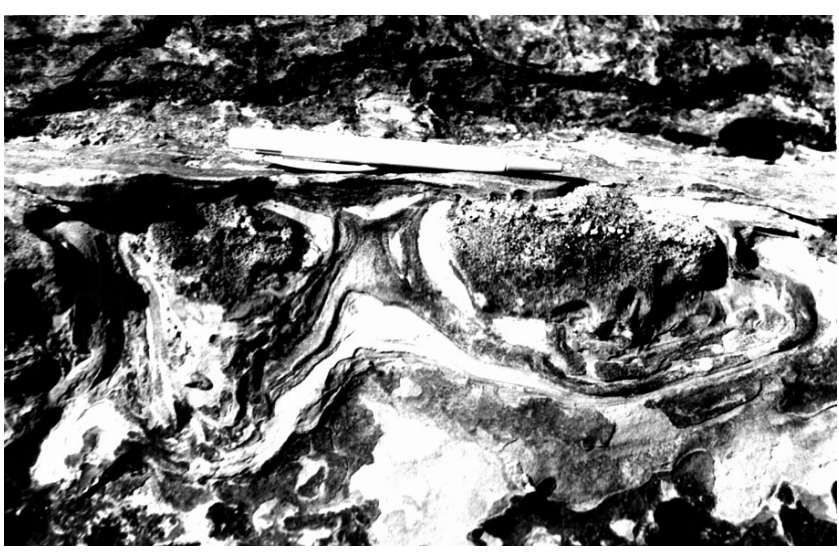

Figure 11. Water escape structure (convolute lamination) in sandstone-siltstone facies association, Talchir Formation. Note truncation of the deformed laminae indicating development near to sediment-water interface.

The clast-supported conglomerate with pronounced reverse grading, development of shear planes at the base, presence of faceted clasts and association with storm-laid inner self sediments suggest emplacement of glaciogenic sediments by subaqueous mass flows. The presence of boulders of cross-stratified red sandstone in the conglomerates suggests long distance transportation or a distal provenance, since there is no exposure of red sandstone bearing sedimentary succession within a limit of $250 \mathrm{~km}$. This evidence lends an indirect support to sheet glacier instead of valley glacier.

The six fining upward sequences in this facies association are inferred to represent six deglaciation sequences (cf. Visser 1997). Conglomerates at the base of each sequence depict glacier advancement, and the finer shoreface sediments above are formed during glacier retreat.

\section{1c Fine sandstone-mudstone facies association (TSM)}

The fine sandstone-mudstone facies association overlies the sandstone-siltstone facies association. Thinly bedded fine-grained sandstone/siltstonemudstone alternation facies (TSM-1) and thick multistoried fine-grained sandstone facies (TSM-2) are the two components of this facies association. Sequential arrangement of these two facies types in this association is shown in figure 12 .

Thinly bedded fine-grained sandstone/siltstonemudstone alternation facies (TSM-1) is represented by less than a centimetre to $20 \mathrm{~cm}$ thick sandstone or siltstone alternating with less than a centimetre to $4 \mathrm{~cm}$ thick mudstone. The sandstone or siltstone is sharp based, and the upper contact with mudstone is generally marked by round crested ripples. The basal part of the mudstone is laminated and the upper part is generally massive. Internally the sandstone/siltstone is plane laminated near the base and followed upward by ripple-drift cross-lamination, spillover ripples or wave ripple cross-lamination. Accretionary hummocks are also present. Prod marks and small grooves are locally present at the soles of these sandstones and siltstones. Slump folds are frequently developed in this facies. Ice-rafted debris or dropstones are absent in this facies. Marine fossil Polyplacophora has been reported from this facies (Sengupta et al 1999).

Thick (20-124 cm) multistoried sandstone facies (TSM-2) is sharp based, and locally show scoured basal contact and are studded with straight and curvilinear gutters, recurved and rectilinear grooves, and bi-directional prod marks. The facies includes massive sandstone near the base, with flat lying mudstone clasts. Majority of the beds exhibit plane lamination, hummocky and swaley cross-stratification including accretionary hummocks. Hummocks and swales are followed upward by plane lamination, ripple-drift cross-lamination and wave ripple lamination or combined flow ripple lamination (cf. Dott and Bourgeois 1982; Walker et al 1983; Myrow and Southard 1991). The sandstone is gradationally overlain by siltstreaked mudstone. Dropstones are absent in this facies. Burrows are common near the top of the sandstone.

The internal primary structures and their organization indicate that both the facies are storm deposits formed above the storm weather wave base (cf. Dott and Bourgeois 1982; Walker et al 1983; Brenchley 1985). Each thin sandstone/siltstonemudstone couplet represents deposition from a waning storm current, while fine-grained multistoried sandstones are amalgamated storm-laid beds. Massive mudstones of this facies association are inferred as autochthonous sediments deposited in pro-deltaic offshore part of the basin. Frequent development of slump folds in TSM-1 indicates a steeper slope of the basin floor, or more precisely a distally steepened shelf. Absence of dropstones in this facies association indicates that there was no floating iceberg and the ice cover became restricted on the continent in response to climatic amelioration.

\subsection{Talchir sedimentary environment}

The Talchir sediments of the Dudhi nala were previously interpreted as glacio-fluvial/lacustrine deposits (Ghosh and Mitra 1967, 1975; Das and Sen 1980). However, Bhattacharya et al (1989), Bose et al (1992) and Mukhopadhyay and Bhattacharya (1994) have advocated a 


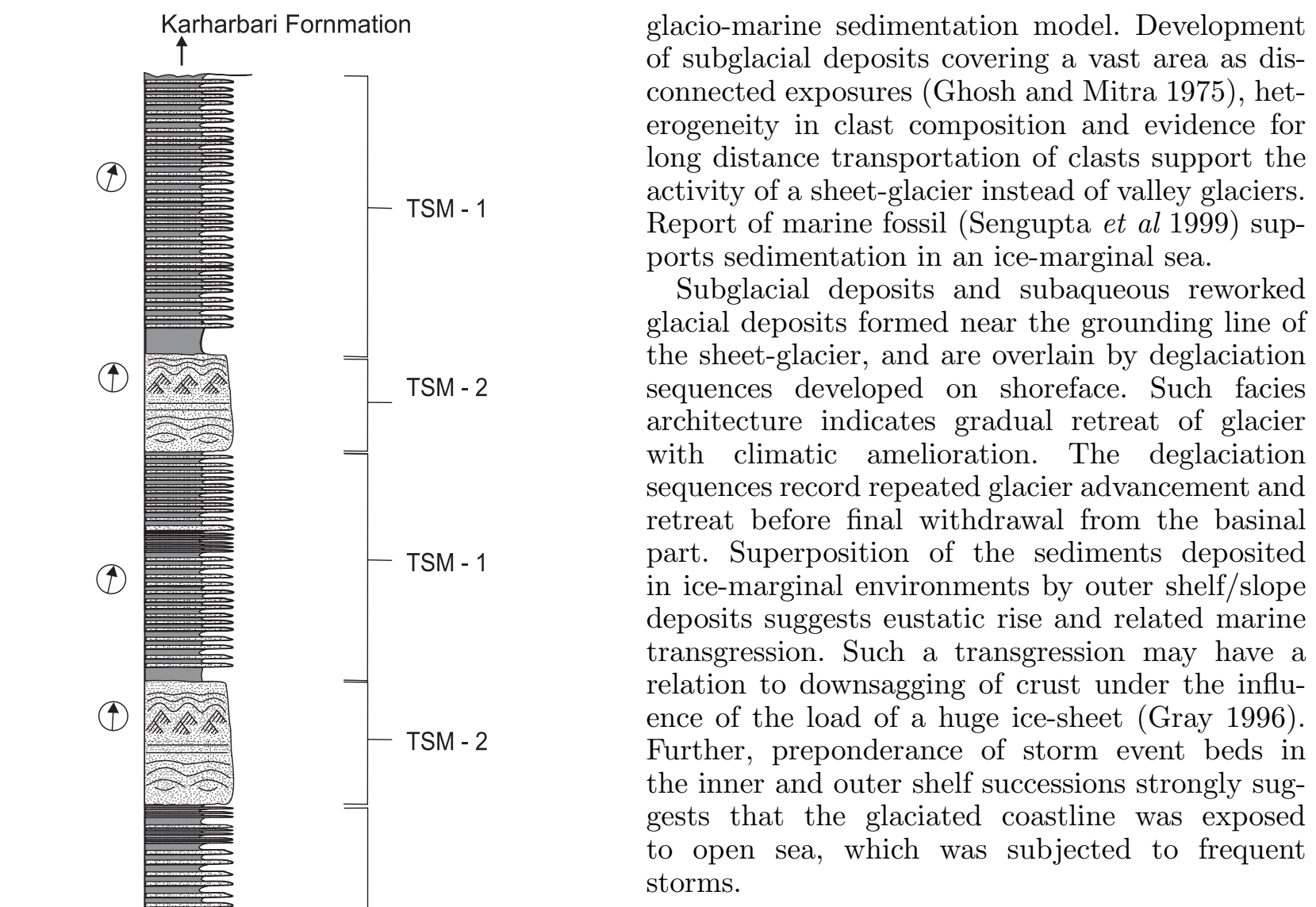

\section{Karharbari Formation}

Coal-bearing sediments of the Karharbari Formation in the Dudhi nala section consist of two facies associations, namely, conglomerate-sandstonemudstone facies association (KCSM) and sandstone-mudstone facies association (KSM). The lower part of the $19 \mathrm{~m}$ thick Karharbari succession in the studied nala section is represented by the conglomerate-sandstone-mudstone facies association forming a fining- and thinning-upward sequence, and in the upper part, sandstonemudstone facies association forms thickening and coarsening upward sequence (figure 13).

\subsection{Facies analysis}

\section{1a Conglomerate-sandstone-mudstone facies association (KCSM)}

Four facies types, namely, disorganized matrixsupported conglomerate facies (KCSM-1), pebbly sandstone facies (KCSM-2), conglomeratesandstone alternation facies (KCSM-3) and coal-bearing mudstone facies (KCSM-4) constitute this facies association. The disorganized matrix-supported conglomerate facies (KCSM-1) (figure 14) is developed at the base of the Karharbari Formation. The conglomerate is lenticular

Figure 12. Measured litholog of the sandstone-mudstone facies association of Talchir Formation, Dudhi nala. 


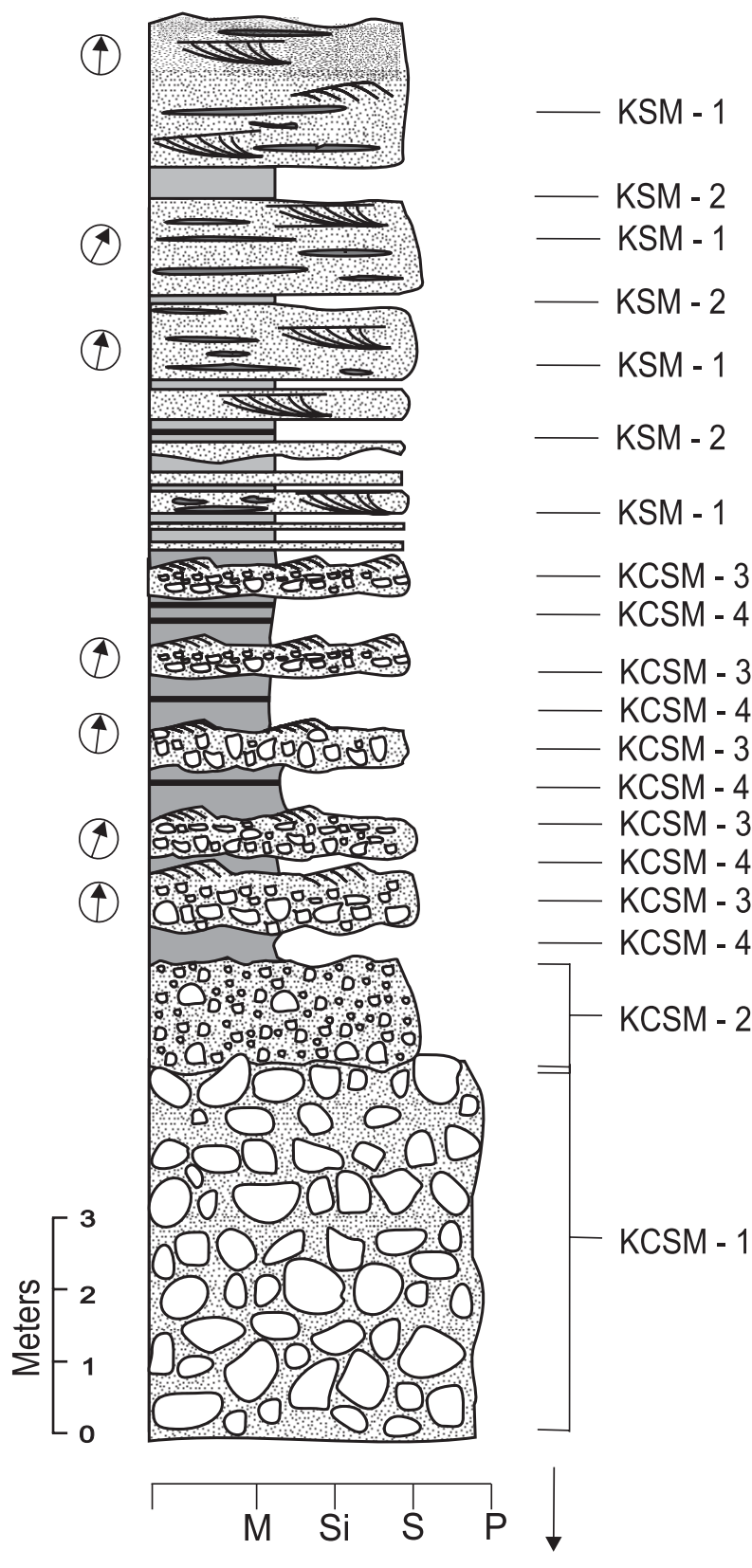

Talchir Formation

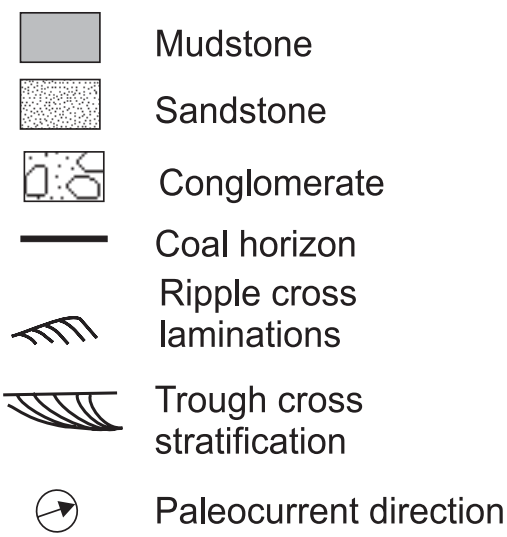

Figure 13. Measured litholog of the Karharbari Formation, Dudhi nala. Note upward thickening of the sandstone beds (KSM-1).

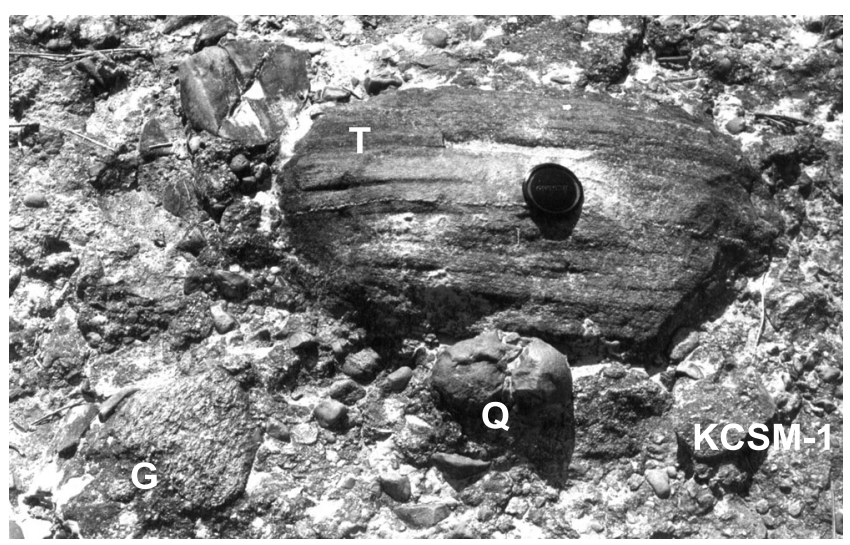

Figure 14. Disorganized matrix-supported conglomerate (KCSM-1) at the base of Karharbari Formation showing presence of clasts of rocks of Talchir Formation $(\mathrm{T})$, granite $(\mathrm{G})$ and quartzite $(\mathrm{Q})$.

and becomes thicker in the down-dip direction. The thickness of the lens is $5 \mathrm{~m}$ in the thickest part. Angular to rounded clasts of green laminated silty-sandstone of the Talchir Formation are common in the conglomerate. Clasts of granite, quartzite and amphibolite are present in subordinate proportion. The clast size varies from 3 to $35 \mathrm{~cm}$ with an average size of $18 \mathrm{~cm}$. The size range of Talchir silty-sandstone clasts is from 14 to $32 \mathrm{~cm}$, with an average size of $22 \mathrm{~cm}$. The conglomerate is largely matrix-supported but may be locally clast-supported. The matrix is totally unsorted and comprises green, gritty sandy-mud. The top surface is undulatory with protruded clasts. White-coloured pebbly arkosic sandstone facies (KCSM-2) overlies the matrix-supported conglomerate facies. The sandstone is coarsegrained, unsorted and massive and contains floating pebbles of granite, quartzite, amphibolite and Talchir sandstone. The clasts are smaller than the clasts in the matrix-supported conglomerate (KCSM-1). The pebbly sandstone occurs as a tabular bed; its basal surface follows the undulations of the upper surface of the underlying conglomerate facies whereas the top surface is planar and sharp. The conglomerate-sandstone alternation facies (KCSM-3) is represented by chaotic, unsorted, matrix-supported conglomerates with scoured base that grades to massive or ripple cross-stratified sandstone towards the top (figure 15). Thickness of the conglomerate units ranges between 4 and $25 \mathrm{~cm}$. Clast size does not exceed $3 \mathrm{~cm}$ and the clast composition is dominated by fine-grained green Talchir sandstone/siltstone. The sandstone units are massive or current ripple laminated. The contact between the conglomerate and overlying sandstone is gradational. The rippled top of the sandstones, at places, is draped by carbonaceous mud. The mudstone facies (KCSM-4) is thinly 


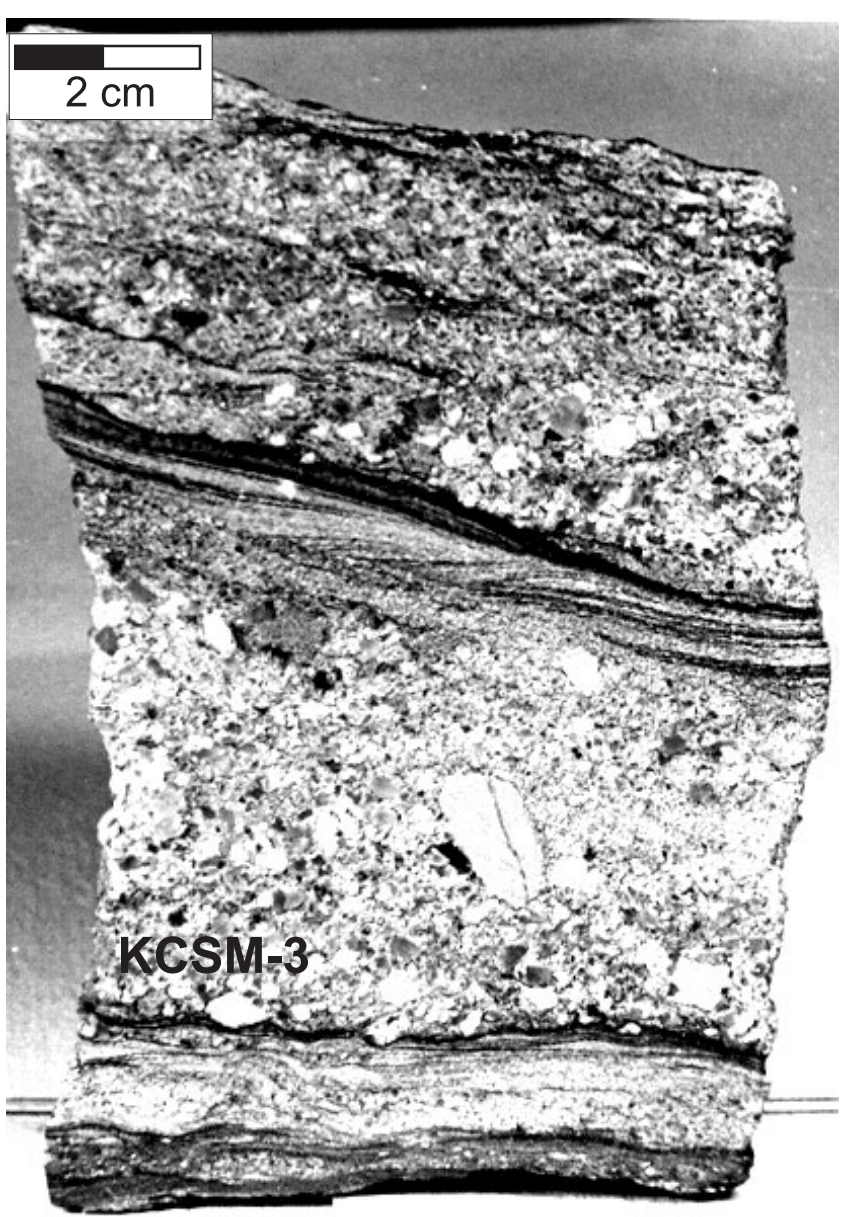

Figure 15. Conglomerate-sandstone alternation facies (KCSM-3) in polished slab. Disorganized conglomerate is overlain by cross-stratified sandstone with diffused contact.

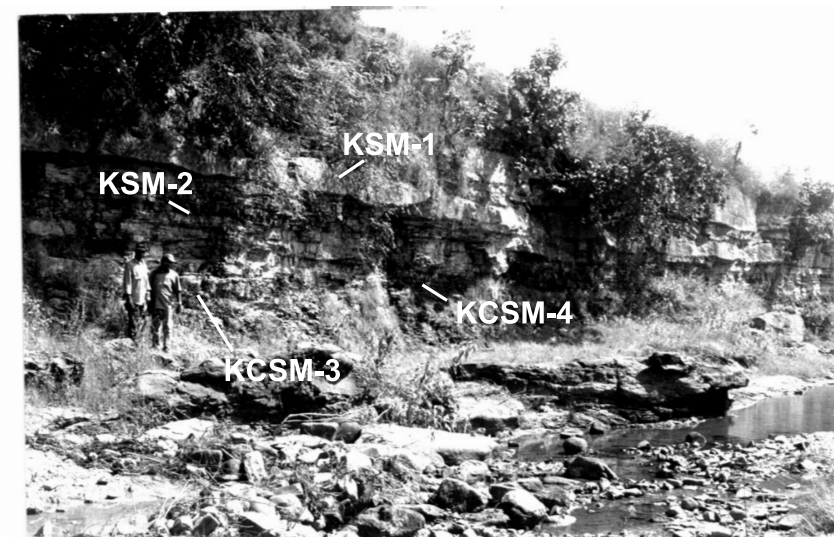

Figure 16. Field photograph of sandstone-mudstone facies association (KSM). Note upward thickening of the sandstone facies.

laminated and contains thin $(4$ to $30 \mathrm{~cm}$ ) layers of coal.

Internal organization of matrix-supported conglomerate facies and pebbly arkosic sandstone facies imply their emplacement by cohesive sediment gravity flows. Development of such coarse-grained sediment gravity flow deposits at the base of the Karharbari succession strongly advocates basin development by faulting. The conglomerate-sandstone alternation facies suggests subaqueous emplacement by sediment gravity flows in which sand was separated from the turbulent gravelly underflow and formed turbidity current (Fisher 1983). Ripple cross-stratification in sandstone and occasional mud draping suggest gradual waning of the turbidity current. Decreasing thickness of the conglomerate units up the succession attests to gradual deepening of the basin and/or waning of intrabasinal tectonism. Repeated intercalation of this facies with laminated coal-bearing mudstone facies indicates that the sediment gravity flows were emplaced in a vegetated lake or swamp. Development of anaerobic reducing environment in the lake or swamps might have favoured the formation of peat (Duchaufour 1982).

\section{1b Sandstone-mudstone facies association (KSM)}

Laterally persistent trough cross-stratified coarsegrained sandstone facies (KSM-1) and laminated carbonaceous mudstone facies (KSM-2) constitute this facies association. The sandstone facies (KSM1 ) is represented by laterally persistent, locally lenticular, pebbly or gritty feldspathic sandstone (figure 16). The feldspar grains in the sandstone are fresh, and carbonized wood particles are common. The basal contact of the sandstone is scoured with concave-up erosional surfaces. The upper contact with mudstone is diffused. The sandstone is trough cross-stratified and the trough sizes decrease towards the top of the bed. Paleocurrent direction deduced from the trough axes is towards $\mathrm{N} 5^{\circ} \mathrm{E}$ with a low dispersion. A crude normal grading of grain size within the sandstone bed is present at places. The thickness of the sandstone beds ranges from 10 to $160 \mathrm{~cm}$. The thicker sandstone beds occur near the top of the succession (figure 16). The mudstone facies (KSM-2) is thinly laminated. Locally, there are coal partings within the mudstone. At places, thin $(2-10 \mathrm{~cm})$ sandstone lenses are present within the mudstone.

The internal organization, lateral persistence, and low dispersion in paleocurrent direction suggest low sinuosity braided river deposition for the sandstone facies (Miall 1988). The laminated mudstone facies is interpreted as lacustrine or flood plain deposit in a low-lying marshland environment (Collinson 1996). The presence of coal in the mudstone indicates development of anaerobic reducing environment for accumulation of peat from vegetable debris. 


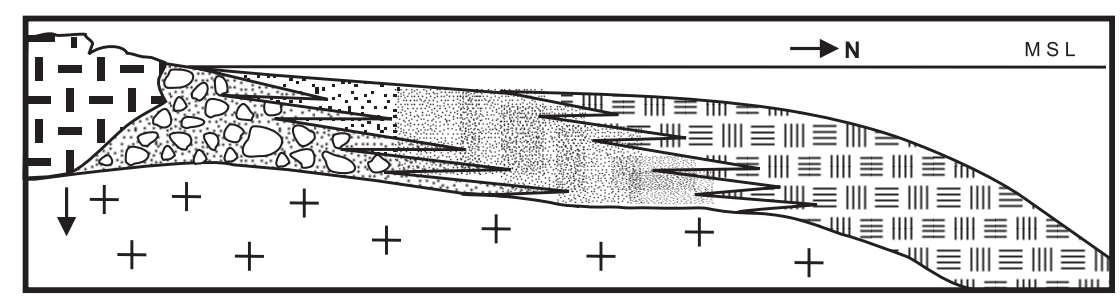

STAGE 1: Glacio-isostatic depression caused by overriding ice sheet. Melting and retreat of glacier, concomitant eustatic rise and deposition of Talchir sediments under transgressive phase.

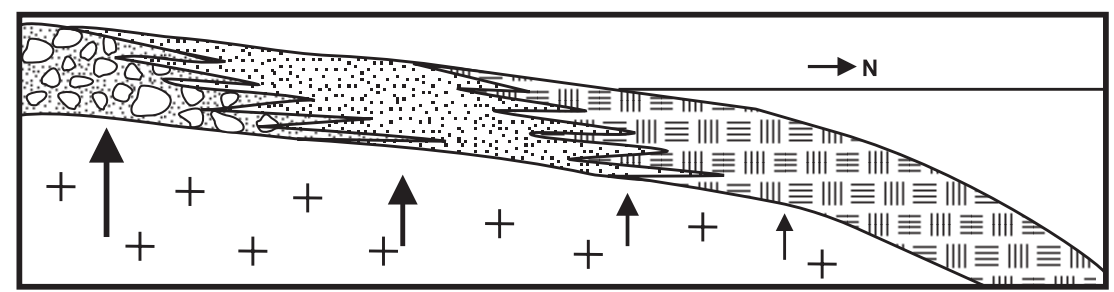

STAGE 2: Upliftment of basement and sediment cover due to glacioisostatic rebound after removal of ice-sheet. Rate of upliftment is less in the basinal part.

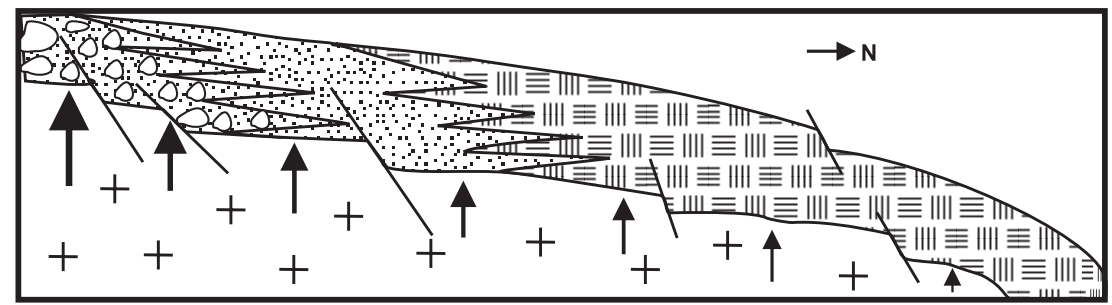

STAGE 3: Normal faults developed due to differential upward movement of basement and sediment cover, and retreat of sea.

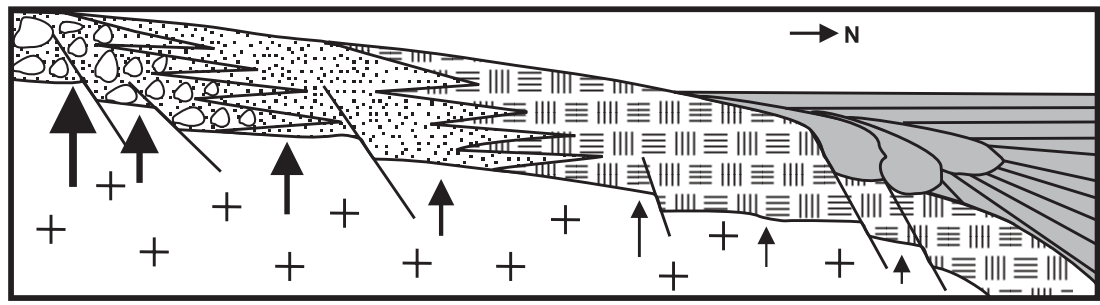

STAGE 4: Deposition of Karharbari sediments on sediments of Talchir Formation in a fault-controlled basin.

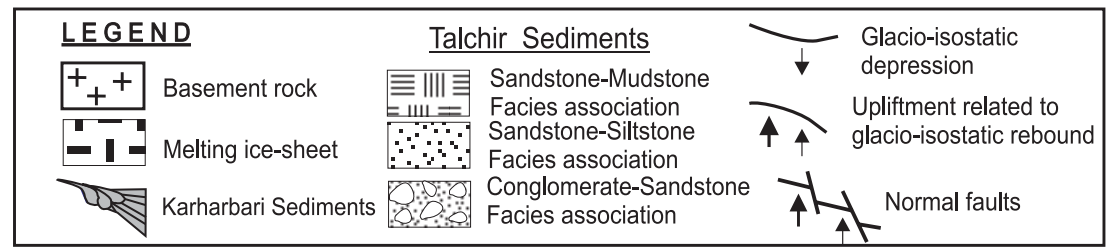

Figure 17. A schematic evolutionary model of the lower Gondwana sediments.

\subsection{Karharbari sedimentary environment}

The Karharbari rocks of the Dudhi nala are interpreted as alluvial fan/fluvial deposits (Ghosh and Mitra 1967, 1975). The present study reveals initial sedimentation by sediment gravity flows, which progrades to a fluviatile-lacustrine depositional milieu in a marshland environment. The chaotic matrix-supported conglomerate (KCSM-1) and pebbly sandstone (KCSM-2) are inferred as subaerial mass flow deposits. The conglomeratesandstone alternation (KCSM-3) and mudstone (KCSM-4) reveals operation of sediment gravity flows in a subaqueous mud-depositing domain. The sandstone-mudstone facies association (KSM1 and 2) represents braided channel deposit. This 
facies association records a gradual progradation of fluvial depositional system in lacustrine environments.

The facies architecture of the Karharbari sediments records a gradual waning in basinal tectonism. Decreasing volume and number of sediment gravity flow deposits with increasing development of fluviatile deposits with time supports this deduction. The characteristic facies architecture further supports control of tectonism over climatic changes on sedimentation pattern during Karharbari time.

\section{Discussion and Conclusion}

The transition from the Talchir Formation to the Karharbari Formation in the West Bokaro basin is interpreted as a result of climatic shift (Ghosh and Mitra 1967, and references therein). The role of tectonism, particularly glacio-tectonics (cf. McCabe and O'Cofaigh 1996) has not been taken into account to explain the observable changes in basin evolution patterns across Talchir-Karharbari contact. The present study reveals an unconformable relationship between Talchir and Karharbari sedimentary successions on the basis of the occurrence of abundant abraded clasts of Talchir sandstone in the basal conglomerate of Karharbari succession. The absence of soft-sediment deformations in the clasts of Talchir rocks in basal Karharbari conglomerate further suggests a time lapse between Talchir and Karharbari sedimentation. Occurrence of such clasts also indicates exhumation of Talchir rocks to act as a source for Karharbari sediments. Such an exhumation or 'basin inversion' is common in basins where removal of ice-sheet has taken place due to climatic amelioration (cf. Coward et al 1991; Giese and Jacobshagen 1991).

In the regions occupied by ice-sheets, the load placed by ice on the earth's crust causes it to sink down, depressing the land surface relative to sea level (Gray 1996). Such glacio-isostatic depression may continue beyond the ice-sheet margins up to a distance of 150-180 km (Benn and Evans 1998). After deglaciation and unloading, glacio-isostatic rebound results in doming and exhumation of crust and cover sediments (cf. Gray 1996). Differential vertical movement during rebound may produce fault-controlled terrestrial basins (Walcott 1970; Andrews 1970).

Elements within the studied facies sequence comprise:

- Glaciogenic sediments that are preserved at the basal part of the Talchir Formation;

- Retreat of glacier and rebounding of the crust, with differential uplift of fault blocks;
- Onlapping of storm-influenced shelf sediments over proximal tillites and resedimented conglomerate-sandstone;

- Deposition of fan and fluviatile sediments of the Karharbari Formation over the shelf deposits of the Talchir Formation.

On the basis of observations made on the Talchir sedimentary successions, a basin evolution model (figure 17) for the initial part of Gondwana sedimentation is suggested as below:

- Late Paleozoic glaciation and related glaciogenic sedimentation (TCS).

- Deglaciation, influx of glacial melt-water with eustatic sea level rise, and deposition of shelf sediments over glacial sediments under transgressive phase (TSS and TSM).

- Post-glacial rebound leading to doming and fracturing of the crust, differential uplift of fault blocks.

- Fault-controlled fan-fluviatile sedimentation (KCSM and KSM) in terrestrial basins.

The model postulated from the Dudhi nala succession may be applicable to other Gondwana basins as well, where coal-bearing terrestrial rocks designated as Karharbari/Barakar Formation overlie glaciomarine Talchir deposits.

\section{Acknowledgements}

HNB recalls valuable discussions with his teacher the Late Prof. S K Chanda during a field trip to Dudhi nala. Helpful comments by Nicholas Eyles (University of Toronto), Stuart Bull (Tasmania University) and Asru K Chaudhuri (Indian Statistical Institute) greatly improved the final manuscript. HNB and BB are grateful to University Grants Commission, Government of India, for financial support (Grant No. F.5-14/2001 (SR-1)). The authors are also thankful to the Department of Geology, Presidency College, Calcutta, for providing infrastructural facilities during the work.

\section{References}

Andrews J T 1970 A geomorphological study of post-glacial uplift with particular reference to Arctic Canada; Institute of British Geographer, Spec. Publ. 2.

Benn D I and Evans D J A 1998 Glaciers and Glaciations (London: Arnold) Pp 26-39.

Bhattacharya H N and Bandyopadhyay S 1998 Seismites in a Proterozoic tidal succession, Singhbhum, Bihar, India; Sediment. Geol. 119 239-252.

Bhattacharya H N, Goswami A and Chakraborty A 2002 Sedimentary facies analysis of a Permo-Carboniferous terminoglacial succession, Saharjuri Basin, Jharkhand, India; J. Geol. Soc. Ind. 60 401-410. 
Bhattacharya H N, Mukhopadhyay G and Bose P K 1989 Hummocky cross-stratification and its hydraulic and climatic implications in Talchir Formation, Dudhi Nala, Hazaribagh, Bihar; J. Geol. Soc. Ind. 34 398-404.

Bose P K, Mukhopadhyay G and Bhattacharya H N 1992 Glaciogenic coarse clastics in a Permo-Carboniferous bedrock trough in India: a sedimentary model; Sediment. Geol. 76 79-97.

Boulton S 1978 Boulder shapes and grain shapes and grain size distribution of debris as indicators of transport paths through a glacier and till genesis; Sedimentology $\mathbf{2 5}$ 773-799.

Brenchley P J 1985 Storm influenced sandstone beds; Modern Geology 9 369-396.

Casshyap S M and Qidwai H A 1971 Paleocurrent analysis of lower Gondwana sedimentary rocks, Pench Valley coalfield, Madhya Pradesh (India); Sediment. Geol. 5 $135-145$

Casshyap S M and Qidwai H A 1974 Glacial sedimentation of late Paleozoic Talchir diamictite, Pench Valley coalfields, Central India; Bull. Geol. Soc. Amer. 85 $749-760$

Casshyap S M and Tewari R C 1982 Facies analysis and paleogeographic implications of a Late Paleozoic glacial outwash deposit, Bihar, India; J. Sediment. Petrol. 52 $1243-1256$.

Casshyap S M and Tewari R C 1988 Depositional models and tectonic evolution of Gondwana basins; Palaeobot. 36 59-66.

Chatterjee G C and Ghosh P K 1970 Tectonic framework of the Peninsular Gondwanas of India; Recd. Geol. Surv. India 98(2) 1-15.

Collinson J D 1996 Alluvial sediments. In: Sedimentary Environments: Processes, Facies and Stratigraphy (ed.) H G Reading (Cambridge USA: Blackwell) Pp. 37-82.

Coward M R P, Gillchrist R and Trudgill B 1991 Extensional structures and their tectonic inversion; Geol. Soc. London Spec. Publ. 56 93-112.

Das S N and Sen D P 1980 Depositional history of PermoCarboniferous tillites and associated sediments in West Bokaro, Gondwana basin, Bihar, India; J. Geol. Soc. India 21 30-38.

De Raaf J F M, Boersma J R and Van Gelder A 1977 Wavegenerated structures and sequences from a shallow marine succession, Lower Carboniferous, County Cork, Ireland; Sedimentology 24 451-483.

Dott R H (Jr.) and Bourgeois J 1982 Hummocky stratification: significance of its variable bedding sequences; Bull. Geol. Soc. Amer. 93 663-680.

Duchaufour P 1982 Pedology; Pedogenesis and Classification (London: Allen and Unwin) Pp. 448.

Dutta A B 1965 Fenestella sp. from Talchirs of Daltongunj coal-field, Bihar; Q. J. Geol. Min. Metall. Soc. India 37 $124-133$.

Fisher R V 1983 Flow transformations in sediment gravity flows; Geology 11 273-274.
Ghosh S K 1954 Discovery of a new locality of marine Gondwana formation; Sci. Cult. 19620.

Ghosh P K and Mitra N D 1967 Talchir sedimentation in West Bokaro Basin; Ind. Minerals 21 1-9.

Ghosh P K and Mitra N D 1975 History of Talchir sedimentation in Damodar Valley basins; Mem. Geol. Surv. India $1051-117$.

Giese P and Jacobshagen V 1991 Inversion tectonics of intracontinental ranges: High and Middle Atlas, Morocco; Geol. Rundschau 81 249-259.

Goldring R and Bridges P 1973 Sublittoral sheet sandstones; J. Sediment. Petrol. 43 736-747.

Gray J M 1996 Glacio-Isostasy, Glacio-Eustasy and relative sea-level change; In: Past Glacial Environments: Sediments, Forms and Techniques (ed.) J Menzies; Oxford: Butterworth-Heinmann 2 315-333.

McCabe M A and O' Cofaigh C 1996 Upper Pleistocene facies sequences and relative sea-level trends along the south coast of Ireland; J. Sediment. Res. 66(2) 376-390.

Miall A D 1988 Facies architecture in clastic sedimentary basins; In: New Perspectives in Basin Analysis (eds) K Kleinspehn and C Paola; New York: Springer-Verlag, Pp. 67-81.

Mukhopadhyay G and Bhattacharya H N 1994 Facies analysis of Talchir sediments (Permo-Carboniferous), Dudhi Nala, Bihar, India - a Glaciomarine Model; $9^{\text {th }}$ Int. Gond. Symp. Hyderabad, India 2 737-753.

Myrow P M and Southard J B 1991 Combined-flow model for vertical stratification sequences in shallow marine storm-deposited beds; J. Sediment. Petrol. 61 202-210.

Nelson C H 1982 Modern shallow-water graded sand layers from storm surges, Bering shelf: a mimic of Bouma sequences and turbidite systems J. Sediment. Petrol. 52 537-545.

Reed F R C 1928 A Permo-Carboniferous marine fauna from Umaria Coalfield; Rec. Geol. Surv. India 60(4) 469-476.

Sengupta S, Chakraborty A and Bhattacharya H N 1999 Fossil Polyplacophora (Mollusca) from Upper Talchir sediments of Dudhi N., Hazaribagh, Bihar; J. Geol. Soc. India 54 523-527.

Veevers J J and Tewari R C 1995 Gondwana master basin of Peninsular India between Tethys and the interior of the Gondwanaland Province of Pangea; Boulder, Colorado, Geol. Soc. Amer. Mem. 187 1-73.

Visser J N J 1997 Deglaciation sequences in the PermoCarboniferous Karoo and Kalahari basins of southern Africa: a tool in the analysis of cyclic glaciomarine basin fills; Sedimentology 44 507-521.

Visser J N J and Hall K J 1985 Boulder beds in the glaciogenic Permo-Carboniferouss Dwyka Formation in South Africa; Sedimentology 52 281-294.

Walcott R I 1970 Isostatic response to loading of the crust in Canada; Can. J. Earth Sci. 7 716-727.

Walker R G, Duke W L and Leckie D A 1983 Hummocky stratification: Significance of its variable bedding sequences: Discussion and reply; Bull. Geol. Soc. Amer. $941245-1251$. 